\title{
Brazilian species of Onychophora with notes on their taxonomy and distribution
}

\author{
Cristiano Sampaio-Costa ${ }^{1,3}$; Amazonas Chagas-Junior ${ }^{1}$ \& Renner L. C. Baptista ${ }^{2}$
}

\author{
${ }^{1}$ Laboratório de Aracnologia, Departamento de Invertebrados, Museu Nacional. Quinta da Boa Vista, São Cristóvão, \\ 20940-040 Rio de Janeiro, Rio de Janeiro, Brasil. \\ ${ }^{2}$ Laboratório de Diversidade de Aracnídeos, Departamento de Zoologia, Instituto de Biologia, Universidade Federal do Rio de \\ Janeiro. Avenida Carlos Chagas Filho 373, Cidade Universitária, 21941-902 Rio de Janeiro, Rio de Janeiro, Brasil. \\ ${ }^{3}$ Corresponding author. E-mail: gigaboardbio@gmail.com
}

\begin{abstract}
A revision of the currently known distribution of Onychophora (velvet worms) in Brazil is presented. Twentyfour morphospecies (half of them undescribed) belonging to four genera of the Peripatidae (Peripatus Guilding, 1826, Epiperipatus Clark, 1913, Macroperipatus Clark, 1913 and Oroperipatus Cockerell, 1908) are recorded. This high number of "unidentified" morphospecies is due to three major reasons: the poor quality of the characters used in species-level identification, the inadequate specimen conservation in ethanol, and, in most cases, the lack of additional specimens for analysis of intra- and inter-specific variation. The morphological characters currently used to separate Peripatidae species present a large degree of variation and may not be sufficient to allow accurate identification. There are records of these animals from 16 states, located in four political regions of the country (North, Center-West, Northeast and Southeast). Oroperipatus balzani is recorded for the first time from Brazil. The southernmost record for Onychophora is Itacuruçá island, Mangaratiba, Rio de Janeiro State (E. edwardsii) and the northernmost is Vila Tepequém, Amajari, Roraima State (Epiperipatus sp. 4). Considering the large territorial area of Brazil and the paucity of localities where Onychophora have been collected, we may expect a total diversity of these animals much larger than the currently known one.
\end{abstract}

KEY WORDS. Brazil; distribution; Peripatidae; taxonomy; velvet worm.

Onychophora is an invertebrate phylum poorly known by the layperson and even by most biologists. However, it is a key taxon for the understanding of the evolution of Panarthropoda (Brusca \& Brusca 1990, Monge-Nájera 1995). Velvet worms are distributed in two large families, with around 200 species, and display a Gondwana distribution (MAYER 2007). Species of Peripatidae are found in tropical areas (West Africa, southern Mexico, Central and South America, Antilles and Southeast Asia), whereas species of Peripatopsidae present a southern temperate distribution (South Africa, Oceania and Chile) (Monge-Nájera 1995).

According to PECK (1975), 60 species and nine subspecies of Peripatidae and one species of Peripatopsidae are known from South and Central America. Species of Peripatidae are known from southern Mexico and the Greater Antilles to southeastern Brazil. On the other hand, Peripatopsidae occurs only in Chile. Up to date, four genera and 11 species have been recorded for Brazil (Oliveira \& Wieloch 2005, SANTANa et al. 2008), the largest species diversity in the Neotropics, notwithstanding the scanty work on the taxonomy of velvet worms. Most Brazilian species display a limited distribution, as Macroperipatus acacioi (Marcus \& Marcus, 1955) (endemic from the Tripuí Ecological Station in the city of Ouro Preto, state of Minas Gerais). In contrast, Epiperipatus edwardsii (Blanchard, 1847) is found from the Central America and the Lesser Antilles to southeastern Brazil (PECK 1975).

The first compilation on velvet worms distribution was proposed in the seminal work of SEDGwick (1888). Besides the many new records of Onychophora, this was the first study to propose the use of both internal and external characters in the taxonomy of the group. Regarding the Neotropical species, Sedgwick cited for the first time unidentified specimens of velvet worms from Brazil, collected in the vicinities of Santarém and Breves, both cities in the state of Pará.

The most important works about Onychophora are the two monographs published in the beginning of the twentieth century by Bouvier $(1905,1907)$. Most of the knowledge on taxonomy, biology, anatomy and distribution of Neotropical velvet worms are still based on those works. Among the 32 species of Peripatidae considered in the first study (Bouvier 1905), five are species from Brazil: Peripatus ohausi Bouvier, 1900, P. brasiliensis Bouvier, 1899, P. edwardsii, P. simoni Bouvier, 1898 and $P$. eiseni Wheeler, 1898.

Years later, ClaRk (1913) presented a new classification for the American species of Peripatus. This author proposed three new subgenera, Plicatoperipatus Clark, 1913, Macroperipatus and Epiperipatus, and a new genus, Metaperipatus Clark, 1913, to accommodate the only know Peripatopsidae from the Ameri- 
cas. Soon after, Clark (1915) discussed and presented a list of hitherto known records of the species of Peripatidae and Peripatopsidae from all over the world.

Brues (1923) published the first map summarizing the geographical distribution of Onychophora throughout the world. Besides a general world map, he elaborated maps depicting the distribution of Onychophora in Australia, West Indies, Africa, South and Central America. Although, this publication analyzed only the distribution of the families and genera, but did not present a detailed list of species and their records.

Marcus (1937) described a new species, Peripatus (Epiperipatus) evelinae Marcus, 1937, from central Brazil. The new species presented a large number of lobopodes (32 and 34), an unseen characteristic in Brazilian velvet worms at that time. Four years later, CARvalHo (1941) described Peripatus (Peripatus) heloisae Carvalho, 1941, from Mato Grosso, also from central Brazil. This species has a distinctive white spot on the head. CARVALHO (1942) added new external and internal features for $P$. heloisae, based on more than 600 additional specimens he collected. Marcus \& Marcus (1955) described a new species, Peripatus acacioi Marcus $\&$ Marcus, 1955, from Tripuí, in the vicinities of the city of Ouro Preto, state of Minas Gerais, also in Brazil. The shape of the cuticular papillae from the new species is similar to P. ohausi, however both species differ in color and presence of accessory teeth.

The first revisionary paper on Brazilian Onychophora was published by Froenuich (1968). He studied a small collection of Onychophora from the former Departamento de Zoologia, Faculdade de Filosofia, Universidade de São Paulo, Brasil. Comments on three species (M. acacioi, P. evelinae and E. edwardsii) were given, and a new species, Peripatus tucupi Froehlich, 1968, was described from the state of Pará.

The last summary of the Onychophora distribution was published by Pеск (1975), but limited to the Neotropical region. In that paper, he described a new genus and gave a revised and updated version of the key to American genera of Onychophora of BOuvier (1905), including the taxa proposed by Clark and himself. He cited nine species, belonging to four genera, collected in 14 different localities from Brazil.

Most papers on Brazilian Onychophora in the last decades dealt with biology and physiology of M. acacioi (e.g., Campiglia \& Lavallard 1973, Lavallard \& Campiglia 1973). Only after the beginning of the current century, studies on taxonomy and distribution of velvet worms began to be published again in Brazil. VASCONCELLOS et al. (2004) recorded specimens of three Peripatus spp. (possibly new) for the first time from the states of Pernambuco and Alagoas. Oliveira \& Wieloch (2005) described a new species of Macroperipatus, M. machadoi Oliveira \& Wieloch, 2005, from the state of Minas Gerais. VAsConcellos et al. (2006) recorded Onychophora species from the Atlantic Rainforest in four states from northeast Brazil (Ceará, Pernambuco, Alagoas and Bahia). The specimens were identified only to the generic level. Later, SANTANA et al. (2008) added the first record of Onychophora from the state of Paraíba, north- eastern Brazil, represented by one specimen collected in the Atlantic Rainforest.

Notwithstanding the above-cited papers, there is no comprehensive paper on the currently known geographical distribution of Onychophora in Brazil. This study presents a species list of Brazilian velvet worms, based on literature, museum specimens and firsthand records. Besides, some characters used in the identification of velvet worms are reexamined and the currently known distribution of Brazilian Onychophora is analyzed.

\section{MATERIAL AND METHODS}

The list below is based on the literature and the analysis of 798 specimens deposited at the following institutions (acronyms and curators given between brackets): Museu Nacional, Universidade Federal do Rio de Janeiro, Rio de Janeiro (MNRJ, A. B. Kury); Museu de Zoologia, Universidade de São Paulo, São Paulo (MZSP, R. Pinto-da-Rocha); Instituto Butantan, São Paulo (IBSP, A. D. Brescovit); and Departamento de Zoologia, Universidade Federal de Minas Gerais, Belo Horizonte (DZUFMG, A. Wieloch). The identification of the specimens follows Bouvier (1905) for the most part, except for the species described after the publication of this revisionary paper. The generic classification used in the species list follows Peck (1975). Species records marked by an asterisk $\left(^{*}\right)$ are those of specimens that were not examined; all information for them are derived from, the literature. Data on localities (distribution section) were gathered from the gazetteers and locality directory of the Falling Rain internet site (http://www.fallingrain.com/world/). The locality record for each specimen was included in a database and afterwards exported to ARC-GIS for map elaboration.

\section{TAXONOMY}

\section{List of Brazilian Onychophora}

\section{Peripatus Guilding, 1826}

\section{Peripatus evelinae Marcus, 1937}

Type-material: BraziL, Minas Gerais/Goiás: between Nova Roma and Cana Brava, Blaser leg. (male lectotype, female allotype and two paratypes, MZSP).

Specimens examined: only types.

Distribution: "Cerrado" areas (dry, open savannas) in the border of Minas Gerais and Goiás states.

\section{Peripatus heloisae Carvalho, 1941 (Fig. 1)}

Type-material: BRAzIL, Mato Grosso: Santa Terezinha (formerly Barra do Tapirapé): A.L. Carvalho leg. (male holotype, MNRJ 0002; female paratype, MNRJ 0003).

Specimens examined: BraziL, Tocantins: Miracema do Tocantins: IX.2001, R. Bertani leg. (3 specimens, IBSP); Mato Grosso: Santa Terezinha: A.L. Carvalho leg. (male holotype, MNRJ 0002); (female paratype, MNRJ 0003); XI.1939, A.L. Carvalho leg. (594 specimens, MNRJ 0001). 

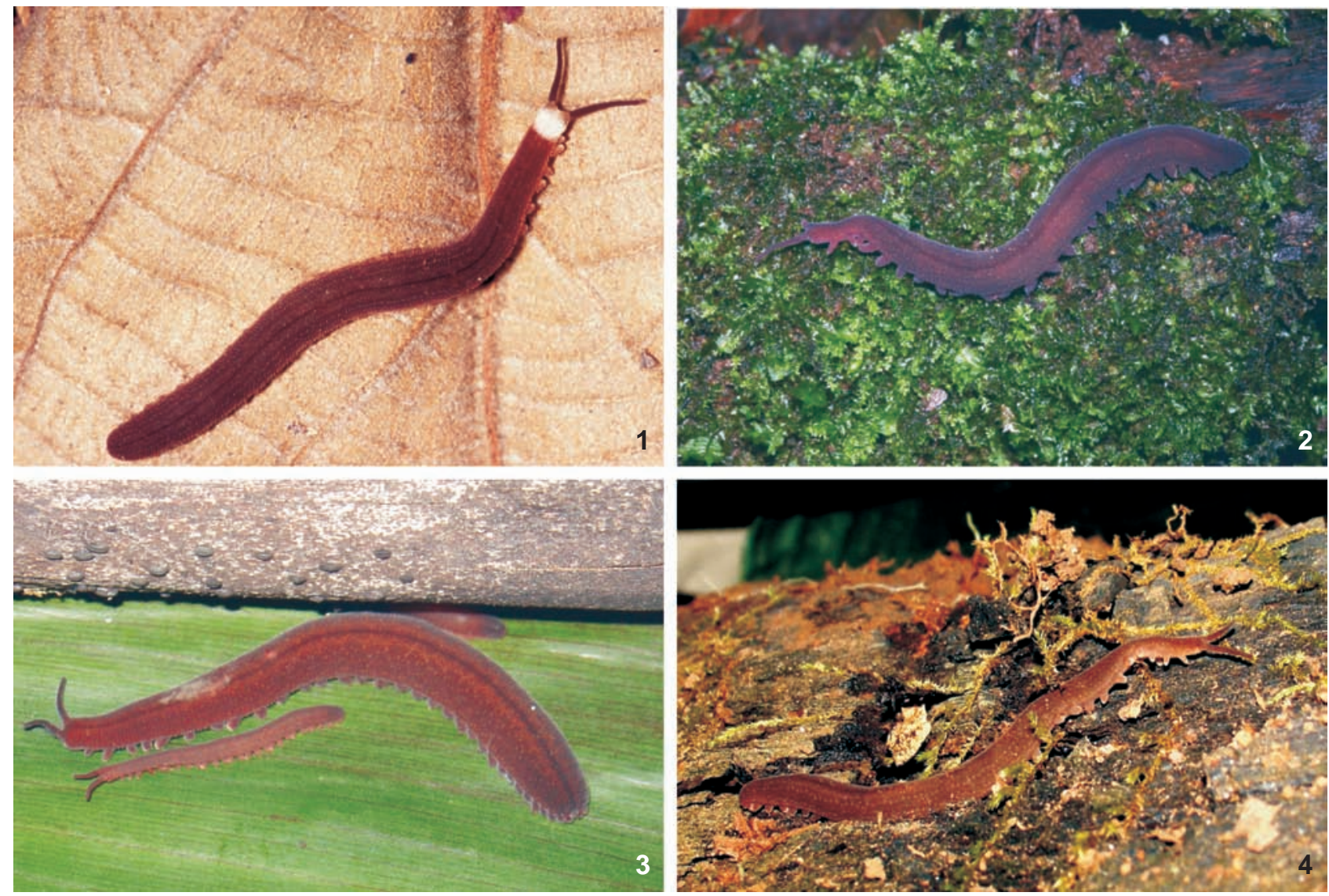

Figures 1-4. Brazilian velvet worms: (1) Peripatus heloisae, adult; (2) Macroperipatus acacioi, adult; (3) Epiperipatus edwardsii, adult female and juvenile; (4) Peripatus sp. 2.

Distribution: "Cerrado" areas from the states of Mato Grosso and Tocantins.

\section{Peripatus sp. 1}

Specimens examined: Brazil, Ceará: Pacoti: Maciço de Baturité: 22.X.1998, A. Percequilo leg. (1 specimen, MZSP).

Distribution: Ceará State.

\section{Peripatus sp. 2 (Figs 4 and 5)}

Specimens examined: BraziL, Tocantins: Porto Nacional: Luzimangue, 13.VII.2007, A. Chagas Jr, A. Giupponi, A. Kury \& A. Pérez leg. (1 specimen, MNRJ 0030); Parque Estadual do Lajeado: 11.VII.2007, A. Chagas Jr, A. Giupponi, A. Kury \& A. Pérez leg. (1 specimen, MNRJ 0031); Lagoa das Confusões: Caverna da Igreja, 08.VII.2007, A. Chagas Jr, A. Giupponi, A. Kury \& A. Pérez leg. (2 specimens, MNRJ 0032, 0033).

Distribution: Tocantins State.

\section{Peripatus sp. 3}

Specimens examined: Brazil, Pará: Conceição do Araguaia: 26.VII.1988, R. Pinto-da-Rocha leg. (1 specimen, MZSP); Tocantins: Palmas: 23.II.2003, (1 specimen, IBSP); Minas Gerais: Simonésia:
Estação Biológica Mata do Sossego, 7-19.III.1999, U. Caramaschi leg., R.N. Feio, H. Niemeyer \& M.F. Napoli leg. (1 spec., MNRJ 0012); Espírito Santo: Colatina: Rio São José (1 specimen, MZSP). Distribution: Pará, Tocantins, Minas Gerais and Espírito Santo states.

\section{Peripatus sp. 4}

Specimens examined: Brazil, Bahia: Porto Seguro: Trancoso, 19.VII.2005, A. Chagas Jr, B. Segal \& E.G. Vasconcelos leg. (1 specimen, MNRJ 0017).

Distribution: Bahia State.

\section{Peripatus sp. 5}

Specimens examined: Brazil, Bahia: Porto Seguro: Reserva Vera Cruz Florestal, 2.XII.1994, O. Marques leg. (1 specimen, MNRJ 0011).

Distribution: Bahia State.

\section{Peripatus sp. 6}

Specimens examined: BrazIL, Mato Grosso: Alto Araguaia: 04.VI.1994, J.M. Marins leg. (1 specimen, MZSP).

Distribution: Mato Grosso State. 


\section{Epiperipatus Clark, 1913}

\section{Epiperipatus brasiliensis (Bouvier, 1899)}

Type-material: Brazil, Pará: Santarém: Wickham leg. (4 syntypes, MNHN, BMNH)*.

Specimens examined: Brazil, Maranhão: Estreito: Rio Farinha, Cachoeira da Usina, 7-14.I.2001, F.C. Straube leg. (1 specimen, MNRJ 0013); Ceará: Crato, R. Alencar leg. (1 specimen, MNRJ 0022).

Distribution: Panama, Venezuela and Brazil (Pará, Maranhão and Ceará states).

\section{Epiperipatus edwardsii (Blanchard, 1847) (Fig. 3)}

Type-material: French GuIANA, Cayenne: 3 mi from mouth Approuage river, Lacordaire (female holotype, MNHN)*.

Specimens examined: Brazil, Pará: Abaetetuba: Piratuba, 1938, A.L. Carvalho leg. (13 males, 11 females, MNRJ 0028); Espírito Santo: Rio Doce, Porto Cachoeiro [On the specimen label, it is written "Porto Cachoeiro, Rio Doce". Porto Cachoeiro is the former name of Santa Leopoldina, a city located around $44 \mathrm{~km}$ from Vitória. However, the Doce river is almost $100 \mathrm{~km}$ away from Santa Leopoldina. So, the precise locality can not be determined, due to the discrepancy in the label], E. Garbe leg. (1 specimen, MZSP 483); Pinheiros: Reserva Biológica Córrego do Veado, 21-23.X.2005, Expedição ESFA leg. (2 specimens, MNRJ 0023, 0027); idem, 22.X.2005, A.P.L. Giupponi, et al. leg. (1 specimen, MNRJ 0026); Linhares: Floresta Nacional de Goytacazes, 25.X.2005, A.P.L. Giupponi, A. Kury, T. Bernabé, T. Souza leg. (1 specimen, MNRJ 0020); idem, 26.X.2005, A.P.L. Giupponi, A. Kury, T. Bernabé leg. (2 specimens, MNRJ 0018); idem, Goytacazes, 13.X.1957, M. Rosa leg. (3 males, 5 females, MNRJ 0029); São Mateus: Reserva Florestal da Companhia do Vale do Rio Doce, VII.1998, A.J. Santos \& G. Machado leg. (3 specimens, MZSP 03709); Santa Teresa: 2005, A.P.L. Giupponi leg. (1 mature and 1 young specimen, MNRJ 0034); idem, Estação Biológica Santa Lúcia, 2830.IV.2004, A.P.L. Giupponi, M.P Milleri \& T. Souza leg. (2 specimens, MNRJ 0015); Rio de Janeiro: Mangaratiba: Ilha de Itacuruçá, Águas Lindas, I.1973, B. Prazeres leg. (1 male, MNRJ 0006).

Distribution: Panama, Trinidad \& Tobago, Venezuela, French Guiana, Surinam, Colombia and Brazil (Pará, Espírito Santo and Rio de Janeiro states).

Remarks: the only specimen known from Itacuruçá, Rio de Janeiro, is dubiously included in E. edwardsii. It is in bad state, and we have not been able to find any character to separate it from the other specimens of E. edwardsii.

\section{Epiperipatus simoni (Bouvier, 1898)}

Type-material: Venezuela, Distrito Federal, Caracas, E. Simon leg. (female holotype, MNHN)*

Specimens examined: Brazil, Rio de Janeiro: Barra de São João, Morro de São João, 21-24.III.2003, Expedição Arachné (2 specimens, MNRJ 0014).
Distribution: Venezuela and Brazil (Pará* and Rio de Janeiro states).

Remarks: the two specimens from Barra de São João are very similar to the redescription and illustration of the type of E. simoni presented by Bouvier (1905). These two specimens have been dubiously included in E. simoni, but they differ in minor details as the presence or absence of frontal organs and the number of small papillae between the primary papilla basis (PPB). The specimens from Barra de São João do not present frontal organs and have 1-7 small papillae between the PPB, whereas E. simoni presents frontal organs and 1-4 small papillae between the PPB, which may prove to be of specific value following further studies.

\section{Epiperipatus tucupi Froehlich, 1968}

Type-material: BraziL, Pará: 1939, E.C. Lima leg. (female holotype and paratype, MZSP).

Specimens examined: only the types.

Distribution: Pará State.

\section{Epiperipatus sp. 1 (Figs 6-8)}

Specimens examined: Brazil: Alagoas: Murici, Estação Ecológica de Murici, Nancy (1 specimen, MNRJ 0035); Murici, Mata da Bananeira, 21.VII.1995, L.M. Freitas \& M.S. Natali (1 specimen, DZUFMG-ONY 0008); Murici, Mata da Bananeira, 21.VII.1995, L.M. Freitas \& M.S. Natali (1 specimen, DZUFMGONY0009).

Distribution: Alagoas State.

\section{Epiperipatus sp. 2}

Specimens examined: BraziL, Espírito Santo: Cariacica, Reserva Florestal Duas Bocas, X.2004, A.L.P. Giupponi, M.P Milleri \& T. Souza leg. (1 male and 1 female, MNRJ 0016); Reserva Florestal Duas Bocas, I.1987, R.L.C. Baptista leg. (1 specimen, MNRJ 0010).

Distribution: Espírito Santo State.

\section{Epiperipatus sp. 3}

Specimens examined: Brazil, Amazonas: 1937, A.L. Carvalho leg. (1 specimen, MNRJ 0024).

Distribution: Amazonas State.

\section{Epiperipatus sp. 4}

Specimens examined: Brazil, Roraima: Tepequém,

11.XII.1994, E.O.S. Sueliano leg. (1 specimen, MZSP).

Distribution: Roraima State.

\section{Epiperipatus sp. 5}

Specimens examined: Brazil, Amapá: Território Federal do Amapá, 18.VI.1966, Froehlich leg. (1 specimen, MZSP); Ferreira Gomes, Sítio Otimari, km 322 da Br. 156, 20.X.2007, J.F. Cláudio \& P. Magno leg. (1 male and 7 females, MNRJ 0036); Porto Grande, Mata do Areal, 21.X.2006, J.F. Cláudio \& P. Magno leg. (4 specimens, MNRJ 0037).

Distribution: Amapá State. 

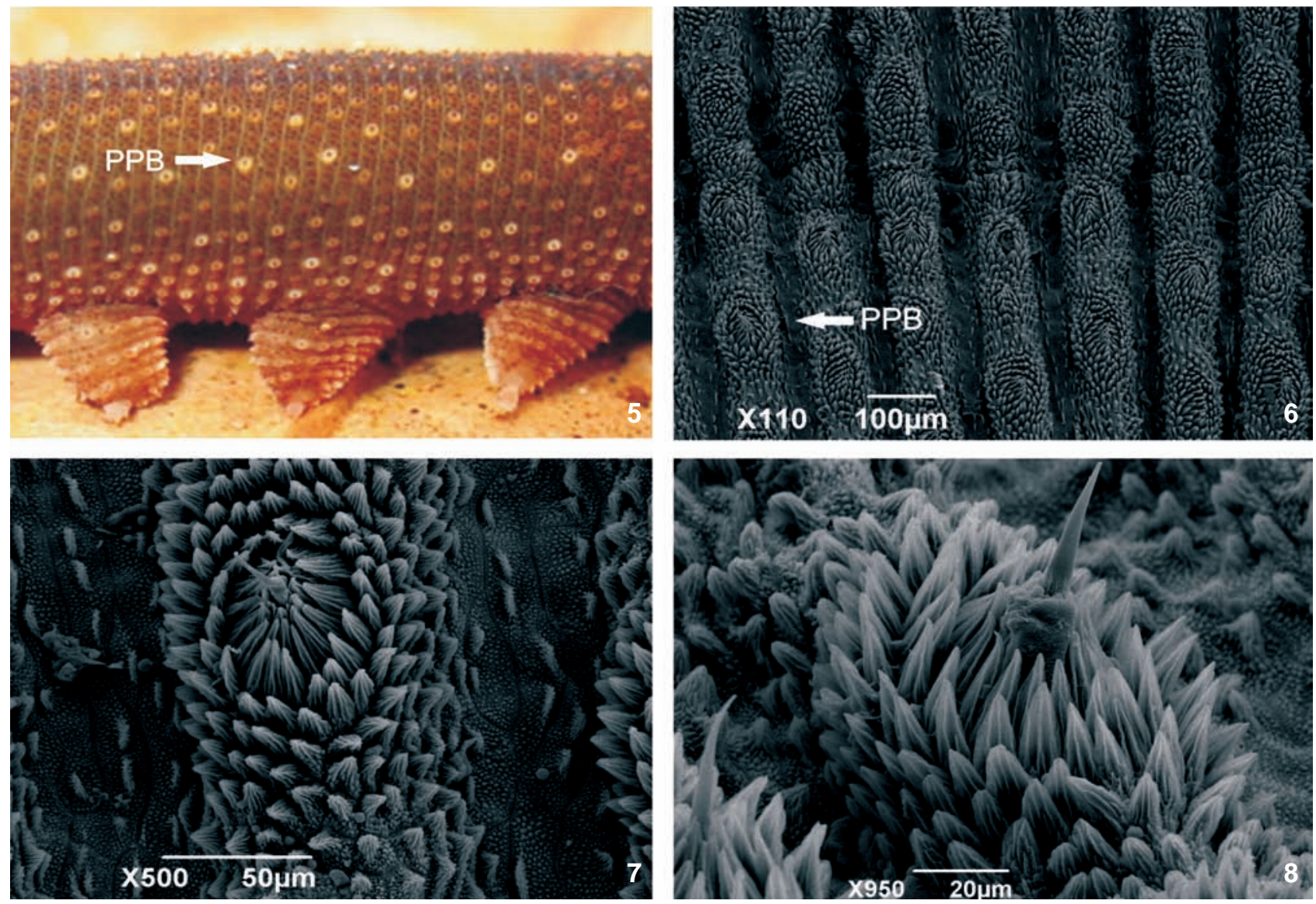

Figures 5-8. (5) Integument of Brazilian Peripatidae: Peripatus sp. 2, detail of the laterodorsal integument; (6) Epiperipatus sp. 1, dorsal view of the disposition of PPB and distance among the folds; (7) Epiperipatus sp. 1, detail of the PPB; (8) Epiperipatus sp. 1, the PPB extent. (PPB) Primary papilla basis.

\section{Macroperipatus Clark, 1913}

Macroperipatus acacioi (Marcus \& Marcus, 1955) (Fig. 2)

Type-material: BraziL, Minas Gerais: Ouro Preto, Tripuí, 17.X.1947, O. Schubart leg. (Holotype male, MZSP); idem (Paratype female, MZSP); A. Costa (7 specimens, syntypes, MZSP).

Specimens examined: BraziL, Minas Gerais: Ouro Preto, Tripuí, 17.X.1947, O. Schubart leg. (Holotype male, MZSP); Ouro Preto, Tripuí, 17.X.1947, O. Schubart leg. (Paratype female, MZSP); Ouro Preto, Tripuí, A. Costa leg. (7 specimens, syntypes, MZSP); Ouro Preto, Tripuí, 12.VII.1961, G. Simões \& A. Costa leg. (1 specimen, MNRJ 0004); Ouro Preto, Tripuí, VII.1961, A. Costa \& J.L.A. Feio leg. (6 specimens, MNRJ 0005); Ouro Preto, J. Moojen leg. (4 specimens, MNRJ 0038); Ouro Preto, Tripuí, IV.2008, I. Oliveira leg. (4 specimens, MNRJ 0039).

Distribution: Minas Gerais State.

\section{* Macroperipatus geayi (Bouvier, 1899)}

Type-material: French Guiana: Carsevenne "Contesté
Franco-Brésilien" (now Amapá State), 1898, F. Geay leg. (female type, MNHN)*.

Distribution: Costa Rica, Panama, French Guiana, Colombia and Brazil (Amapá State).

Macroperipatus machadoi Oliveira \& Wieloch, 2005

Type-material: BraziL, Minas Gerais: Caratinga, Reserva Particular do Patrimônio Natural Feliciano Miguel Abdala, VII.1984 (Holotype female, DZUFMG-ONY 0001); idem, 21.XII.2001, J.C. Silva-Júnior leg. (male, DZUFMG-ONY 0002); idem, 27.VII.2000, J.C. Silva-Júnior leg. (male, DZUFMG-ONY 0003).

Specimens examined: BrazIL, Minas Gerais: Caratinga, Reserva Particular do Patrimônio Natural Feliciano Miguel Abdala, VII.1984 (Holotype female, DZUFMG-ONY 0001); Caratinga, Reserva Particular do Patrimônio Natural Feliciano Miguel Abdala, 21.XII.2001, J.C. Silva-Júnior leg. (male, DZUFMG-ONY 0002); Caratinga, Reserva Particular do Patrimônio Natural Feliciano Miguel Abdala, 27.VII.2000, J.C. Silva-Júnior leg. (male, DZUFMG-ONY 0003).

Distribution: Minas Gerais State. 


\section{* Macroperipatus ohausi (Bouvier, 1900)}

Type-material: BraziL, Rio de Janeiro: Petrópolis, 16.VIII.1898, Dr. Ohaus (two female types, ZMH and MNHN)*.

Distribution: Rio de Janeiro State.

Remarks: the additional specimen from MZSP examined by READ (1988a) was not located in that collection (R. Pinto-daRocha, Universidade de São Paulo, pers. comm.). Following information from the collector of the MZSP specimen (C. A. Brandão, Museu de Zoologia de São Paulo pers. comm.), we tried to collect new specimens on the precise collecting site. However, we have not been successful, as the site is located at an area of urban sprawl in Petrópolis. So, M. ohausi has not been captured again since 1981, despite our efforts to collect it.

\section{Macroperipatus sp. 1}

Specimens examined: Brazil, Pernambuco: Recife, Dois Irmãos, O. Schubart leg. (1 specimen, female, MNRJ 0025)

Distribution: Pernambuco State.

\section{Oroperipatus Cockerell, 1908}

\section{Oroperipatus balzani (Camerano, 1897)}

Type-material: Bolivia, Coroico and Chulumani provinces (two male types, MZT and MHNG)*

Specimens examined: BrAZIL, Acre: Marechal Thaumaturgo, REAJ, 24.VIII.94, A.J. Cardoso leg. (1 specimen, MNRJ 0021).

Distribution: Bolivia and Brazil (Acre State).

\section{*Oroperipatus eiseni (Wheeler, 1898)}

Type-material: Mexico, Nayarit, Tepic (87 types, BMNH and $\mathrm{MNHN}$ )*

Distribution: Mexico, Panama and Brazil (Amazonas State).

\section{DISCUSSION}

In this study, 24 morphospecies of Onychophora are recorded from Brazil, 12 of them corresponding to described species (see taxonomic list above), distributed in four genera: Peripatus, Epiperipatus, Macroperipatus, and Oroperipatus. Up to now, $O$. balzani was known only from Bolivia. It is recorded for the first time from Brazil in this paper. The Brazilian records of M. geayi, M. ohausi and O. eiseni are based only on the literature. The other 12 morphospecies are not ascribed to any described species. This high number of "unidentified" morphospecies is due to three major reasons: the poor quality of the characters used in specieslevel identification, the inadequate specimen conservation in ethanol, and, in most cases, the lack of additional specimens for analysis of intra- and inter-specific variation.

Since Bouvien's monograph on Onychophora (1905), few additional characters have been used in the taxonomy of Peripatidae. One character used by Bouvier to separate Peripatidae into two large groups, "Peripates andicoles" and "Peripates carailbes", is the number of papillae in the foot of the lobopods IV-V. The "Peripates andicoles" (now included in Oroperipatus) present four or more papillae in the foot of lobopods IV-V. On the other hand, "Peripates caraïbes" (now included in Peripatus, Epiperipatus and Macroperipatus) present only three papillae in those feet. This character was proposed by Bouvier (1905) and is well known in the literature.

The diagnosis of the three genera included in the "Peripates caraïbes" is difficult and not clearly stated in the current taxonomic literature. After READ (1988a), "the apparent lack of good specific characters and the great uniformity among genera within the Peripatidae, particularly the large Caribbean group, has been the great obstacle to taxonomic progress". In the same paper, she revised the morphological characters used to separate genera in Peripatidae through SEM examination, and pointed to great variability in the integument characters. She remarked that the degree of body contraction of one specimen may greatly affect the appearance of its integument. A distended specimen shows a very different pattern in the shape and disposition of the dorsal papillae in comparison to a contracted one, for example. We also observed a large variation in integument characters, as color pattern and shape and distribution of dorsal papillae. Most of this variation may probably be explained by the use of different methods to fixing and preserving the specimens, as well as by the variable time-span they are kept in collections.

Following the papers by Bouvier (1905), Clark (1913) and Peck (1975), the shape of the basis of the primary papillae, called "papilles principales" by Bouvier, and the disposition of the dorsal papillae on the folds allow for the separation among Peripatus, Epiperipatus and Macroperipatus. However, there is variation in the shape and disposition of the papillae even within one genus, as for example in Peripatus. The primary papilla bases (PPB from now on figure 5) of Peripatus are round and placed far apart from each other. Epiperipatus also has round PPB (Figs 6-8), but they are close together. Finally, Macroperipatus presents PPB almost square and placed not far apart. As remarked above, the fixing method and preservation period may have a substantial effect upon the shape and disposition of PPB. In several of the 12 "unidentified" morphospecies in our list, it was easy to find specimens presenting either papillae closely spaced or placed farther away, as for example in Peripatus sp. 3 and Peripatus sp. 2 .

The diagnostic character for Macroperipatus is the square PPB (Bouvier 1905, Clark 1913, Peck 1975), as found in $M$. torquatus (Kennel, 1883) (type-species), M. geayi, M. valerioi Morera-Brenes \& Léon, 1986 and M. perrieri (Bouvier, 1899). On the other hand, M. acacioi and M. machadoi have PPB varying from subquadrate to round, but never square PPB. We have not examined specimens from M. ohausi, the other species of Macroperipatus from Brazil, but READ (1988a) noted that it also does not have the square basis. According to our results and also those from READ (1988a), the square PPB seems to be restricted to the Macroperipatus species from Central America and northern South America. The species from southeast Brazil bear PPB similar to the ones found in Peripatus or Epiperipatus.

An additional character used to separate velvet worm species is the contrasting color pattern (for example, stripes, 
lozenges etc.) over and around the median dorsal line. The pattern of light lozenges over a darker background is found in at least three Epiperipatus species (E. trinidadensis (Sedgwick, 1888), E. broadwayi (Clark, 1913) and E. edwardsii) and also in M. acacioi. In contrast, the lozenges are not clearly seen in some E. edwardsii specimens from Espírito Santo State, and may even not be noticed at all. Most Brazilian Onychophora have brownish to purple-brown hues, often presenting a darker, thin, stripe over the median dorsal line. P. heloisae bears a contrasting whitish spot just behind the head.

Among the nine Epiperipatus morphospecies we found, E. edwardsii and E. brasiliensis are easily identified. We were not able to examine any E. imthurmi specimen. Regarding the other Epiperipatus morphospecies, the analysis of the outer morphological characters were not enough to allow an accurate identification. For example, Epiperipatus sp. 5 has the leg number and irregular papillae disposition found in E. imthurmi, but it differs in coloration. Epiperipatus sp. 5 is dark purple, whereas E. imthurmi may present colors varying from orange to brown.

The only "unidentified" morphospecies of Macroperipatus seems to be close to M. ohausi, but it is found only in Pernambuco State, northeastern Brazil, while M. ohausi is known only from Rio de Janeiro State, southeastern Brazil. Both species present jaw blades with an inner accessory tooth and well-developed frontal organs. Macroperipatus sp. 1, though, displays a row of 11 teeth placed after the accessory tooth of the inner jaw, absence of secondary papillae placed laterally to the primary ones, and 30 pairs of legs, contrasting to the 10 teeth, presence of such secondary papillae and 27-28 pairs of legs found in M. ohausi (after Bouvier 1905). Summing up, the gap found in the morphological characters and the distance between localities indicate that M. ohausi and Macroperipatus sp. 1 are probably distinct species.

As shown above, the morphological characters currently used to separate Peripatidae species present a large degree of variation and may not be sufficient to allow accurate identification. The use of characters of inner structures, as number of teeth in the jaws, and SEM may yield good results when applied to Brazilian Onychophora, as has been noticed by READ (1988 a, b) and MAYer (2007) in other countries.

Most papers on the distribution of Onychophora are worldwide-based, and do not present detailed records for each country. Considering Brazilian Onychophora, most records are restricted to the description of species. Also, many new records have been presented in abstracts of zoology meetings, including new but invalid scientific names.

During our studies, we examined specimens of velvet worms from twelve of the thirteen Brazilian states already cited in the literature (Amazonas, Pará, Ceará, Pernambuco, Alagoas, Bahia, Tocantins, Goiás, Mato Grosso, Minas Gerais, Espírito Santo and Rio de Janeiro). The exception is Paraíba, as we have not been able to examine upon any specimen from it. Besides, we added first-time records for three states (Roraima, Acre and
Maranhão) and 27 new localities from Brazil. Summing up, Onychophora are currently known from 16 states, from all Brazilian regions, except the South. The southernmost record for Onychophora is Itacuruçá island, Mangaratiba, Rio de Janeiro State (E. edwardsii) and the northernmost is Vila Tepequém, Amajari, Roraima State (Epiperipatus sp. 4) (Fig. 9).

Most described Brazilian species are certainly endemic, as they are known only from their type-locality (e.g., E. tucupi, M. acacioi, M. ohausi, M. machadoi and P. evelinae). Some species are known from just one additional collection outside the type-locality (e.g., P. heloisae, O. eiseni and O. balzani), but others have what seems to be wide distributions (e.g., E. edwardsii, E. simoni and E. brasiliensis). Epiperipatus edwardsii is the most widespread species in Brazil, but most records are from Pará and Espírito Santo states.

Species of Oroperipatus are known only from the state of Acre, northwestern Brazil. Macroperipatus spp. are found in several southeastern states and also from an isolated record from Pernambuco, northeastern Brazil. In contrast, species of Epiperipatus and Peripatus are found on a wide geographical area covering most states in Brazil (Fig. 9).

The 24 here recognized morphospecies of Peripatidae represent a substantial increase over the 11 species cited by OliverRA \& Wieloch (2005) and Santana et al. (2008). Also, the known distribution of velvet worms now covers most Brazilian states, with the exception of the South region. Considering the large territorial area of Brazil and the paucity of localities where Onychophora have been collected, we may expect a total diversity of these animals much larger than the currently known one.

As we pointed out before, the method of preservation of the specimens exerts a large effect over the characters currently used in Peripatidae taxonomy. Most specimens kept in museums do not allow a precise identification but they are still useful as mementos of the distribution of velvet worms and pinpoints for future collection. Taking in consideration the apparently limited capacity of dispersal of most velvet worms, additional collection effort is badly needed, as many of the old localities are under intense human pressure and extinction looms at the corner.

\section{ACKNOWLEDGMENTS}

We thank Ricardo Pinto-da-Rocha (MZSP) and Ivo S. de Oliveira (MNRJ/UFMG), for loaning specimens used in this study. Eduardo Vasconcelos, for the precious informations on the Onychophora from MZSP collection. To Elivaldo de Lima for SEM operation at the Center for Scanning Electron Microscopy of Museu Nacional, UFRJ. The establishment of this Center was made possible by a grant from Cenpes/Petrobras, and is part of the company's Thematic Network for Marine Environmental Monitoring. Glauco Machado, Rogério Bertani, Cleide Mendonça and Antonio Brescovit, for the donation of specimens to the MNRJ collection. Carlos R.F. Brandão (MZSP) for the precious information on the locality in Petrópolis of M. ohausi and Adriano 


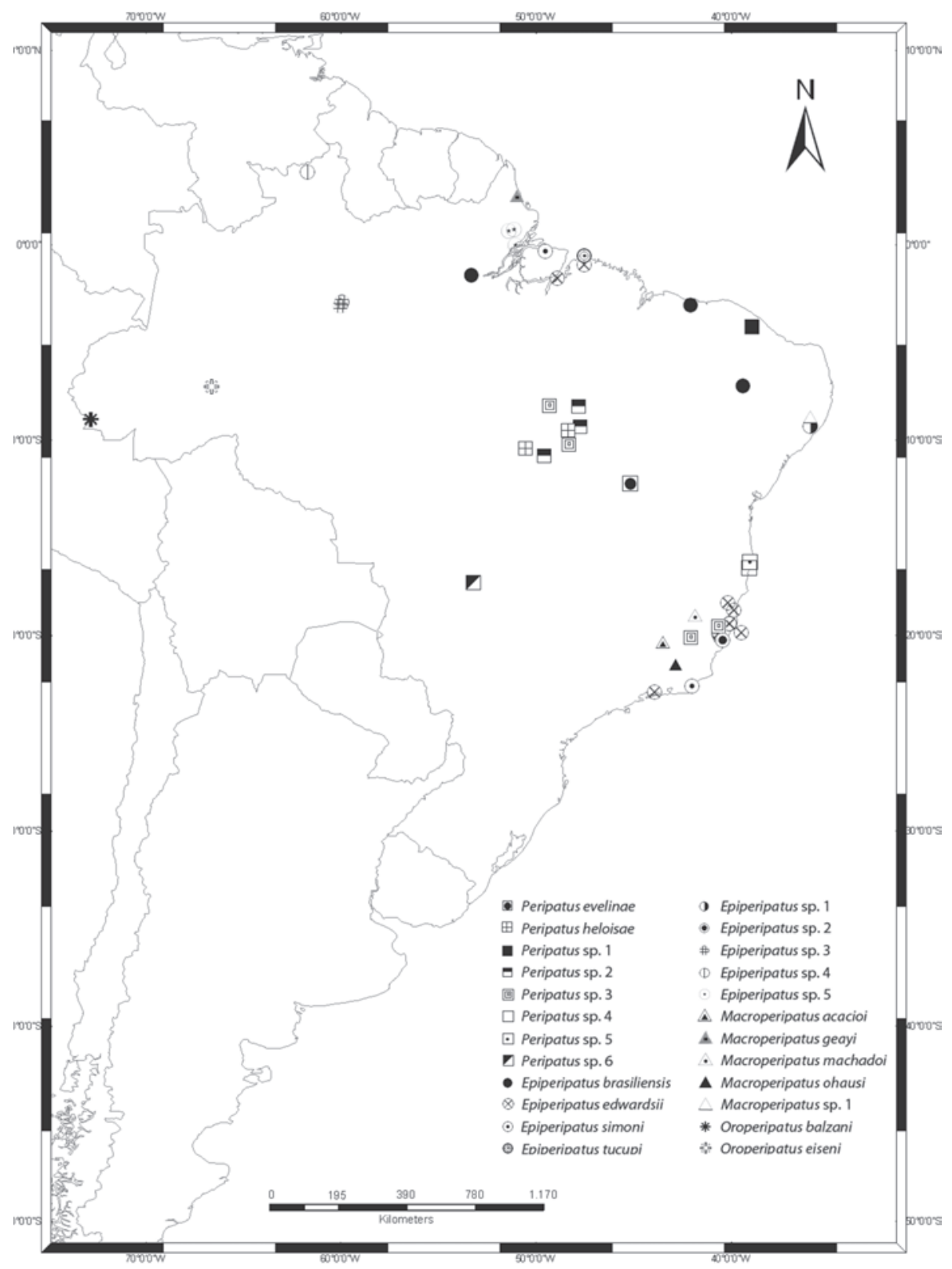

Figure 9. Map showing the known distribution of the 24 morphospecies of Onychophora from Brazil.

Kury for helpful suggestions and support to this work. Rogério Bertani and Abel P. González for the photos. CNPq and FAPERJ, for the grants given to the two first authors.

\section{LITERATURE CITED}

Bouvier, E.L. 1905. Monographie des Onychophores 1. Annales des Sciences Naturelles, Zoologie (Série 9) 2: 1-383.

Bouvier, E.L. 1907. Monographie des Onychophores 2. Annales des Sciences Naturelles, Zoologie (Série 9) 5: 61-318.
BRues, C.T. 1923. The geographical distribution of the Onychophora. American Naturalist 57 (650): 210-217.

Brues, C.T. 1925. Notes on neotropical Onychophora. Psyche 32 (3): 159-165.

BRusCA, R.C. \& G.J. BRusCA. 1990. Invertebrates. Sunderland, Sinauer Associates Inc. Publishers, XII+968p.

Campiglia, S. \& R. Lavallard. 1973. Contribution a la biologie de Peripatus acacioi Marcus et Marcus. II. Variations du poids des animaux en fonction du sexe et du nombre des lobopodes. 
Boletim de Zoologia e Biologia Marinha 30: 499-502.

Carvalho, A.L. 1941. Nota prévia sôbre uma nova espécie de "Peripatus" do Brasil Central. Revista Brasileira de Biologia 1 (4): 447-448.

Carvalho, A.L. 1942. Sobre "Peripatus heloisae", do Brasil Central. Boletim do Museu Nacional 2: 57-89.

Clark, A.H. 1913. A revision of the American species of Peripatus. Proceedings of the Biological Society of Washington 26: 15-19.

Clark, A.H. 1915. The present distribution of the Onychophora, a group of terrestrial invertebrates. Smithsonian Institution Miscellanean Collection 65 (1): 1-25.

FaLLing Rain Genomics, Inc. 1996-2006. Global Gazetteer Version 2.1. Available online at: http://www.fallingrain.com/world [Accessed: 09.VII.2008].

Froenlich, C.G. 1968. On some Brazilian onychophores. Beitrage zur Neotropischen Fauna 5 (3): 160-171.

Lavallard, R. \& S. Campiglia. 1973. Contribution a la biologie de Peripatus acacioi Marcus et Marcus. I. Pourcentage des sexes et variations du nombre des lobopodes dans un echantillonnage de plusieurs certaines d'individus. Boletim de Zoologia e Biologia Marinha 30: 483-498.

Marcus, E. 1937. Um Onychophoro novo, Peripatus (Epiperipatus) evelinae, spec. nov. de Goyaz. Revista do Museu Paulista 21: 903-910.

Marcus, E. \& E. Marcus. 1955. A new Peripatus from Minas Gerais, Brazil. Anais da Academia Brasileira de Ciências 27 (2): 189-193.

Mayer, G. 2007. Metaperipatus inae sp. nov. (Onychophora: Peripatopsidae) from Chile with a novel ovarian type and dermal insemination. Zootaxa 1440: 21-37.

Monge-NÁjera, J. 1995. Phylogeny, biogeography and reproductive trends in the Onychophora. Zoological Journal of the Linnean Society of London 114: 21-60.
Oliveira, I.S. \& A.H. Wieloch. 2005. Macroperipatus machadoi sp. nov. (Onychophora: Peripatidae) da Floresta Atlântica de Minas Gerais. Lundiana International Journal of Biodiversity 6: 61-65.

Peck, S.B. 1975. A review of the New World Onychophora with the description of a new cavernicolous genus and species from Jamaica. Psyche 82 (3-4): 341-358.

READ, V.M.S.J. 1988a. The application of scanning electron microscopy to the systematics of the neotropical Peripatidae (Onychophora). Zoological Journal of the Linnean Society of London 93 (3): 187-223.

READ, V.M.S.J. 1988b. The Onychophora of Trinidad, Tobago and Lesser Antilies. Zoological Journal of the Linnean Society of London 93 (3): 225-257.

Santana, G.G.; W.O. Almeida; R.R.N. Alves \& A. Vasconcellos. 2008. Extension of the northern distribution of Onychophora in the Brazilian Atlantic Forest. Biotemas 21 (2): 161163.

SedGWICK, A. 1888. A monograph on the species and distribution of the genus Peripatus (Guilding). Quarterly Journal of Microscopical Sciences 28 (112): 431-493.

Sedgwick, A. 1908. The distribution and classification of the Onychophora. Quarterly Journal of Microscopical Sciences 52 (207): 379-406.

Vasconcellos, A.; W.O. Almeida \& E.C.C. Eloy. 2004. Onychophora de florestas úmidas do complexo da Mata Atlântica do nordeste brasileiro e sua importância para conservação e estudos sistemáticos, p. 139-144. In: K.C. Porto; J.J.P. Cabral \& M. TABARElli (Eds). Brejos de Altitude: história natural, ecologia e conservação. Brasília, Ministério do Meio Ambiente, Série Biodiversidade 9, 324p.

Vasconcellos, A.; W.O. Almeida \& L.A. Souza. 2006. Onychophora in humid forests of northeast Brazil. Brazilian Journal of Biology 66 (1): 187-189.

Submitted: 02.X.2008; Accepted: 25.VIII.2009.

Editorial responsibility: Gabriel Mejdalani 